\title{
Introduction: Human-Animal Relationships From a Long-Term Perspective
}

\author{
Kristin Armstrong Oma' [1] \& Joakim Goldhahn² (),
}

Humans, like other animals, are inextricably bound to their local complex web-of-life and cannot exist outside of relationally interwoven ecosystems. Humans are, as such, rooted in a multispecies universe. Human and non-human animals in their variety of forms and abilities have been commensal, companions, prey, and hunters, and archaeology must take this fundamental fact - the cohabiting of the world - to heart. Human societies are, therefore, not so much human as web-of-species societies. Recently, anthropological theory has explored non-modern societies from the perspective of an anthropology of life which incorporates relationality of local humans and non-human animals, a pursuit that is significant for the diverse contributions in this special section of Current Swedish Archaeology: a themed section which deals with past multispecies intra-actions in a long-term perspective.

\footnotetext{
${ }^{1}$ Museum of Archaeology, University of Stavanger kristin.a.oma@uis.no

${ }^{2}$ Kimberley Foundation Ian Potter Chair in Rock Art, School of Social Sciences, University of Western Australia joakim.goldhahn@uwa.edu.au
}

This is an Open Access article distributed under the terms of the Creative Commons 4.0 International licence (CC BY 4.0) (http://creativecommons.org/licenses/by/4.0/), which permits unrestricted use, distribution, and reproduction in any medium, provided the original work is properly cited. 
In this themed section of the CSA 2020 issue, we have invited archaeologists with different backgrounds and specialist knowledge to ponder what entanglements of human and non-human animals mean for archaeological studies of societies from a deep-time perspective, with a particular focus on human-animal multispecies relationships (Pilaar Birch 20I8). Some kind of relationship between humans and different animal species and/or individuals is a basic fundament for all societies. A poignant example is the pandemic-crisis of 2020 with its global spread of the virus COVID-I9 and its influence on many aspects of human societies, not only its detrimental influence on health and economy but also innovation in communication strategies and material culture. The virus is thought to stem from bats, possibly transmitted to pangolins, and ultimately to humans at one of Wuhan's so-called wet markets (Andersen et al. 2020; Huang et al. 2020). In this we see how human encroachment on wilderness, bringing wild, critically endangered animals into human societies, has wide-reaching global consequences and effectively changes human societies.

The impact of COVID-I9 on our lives demonstrates how human-animal relationships in current societies can have both unforeseen and unintended consequences. If there is a constant to human society through time it is exactly this: that the web-of-life changes in unexpected ways. Therefore, different time periods and cultures that archaeologists study have different pre-requisites regarding the embeddedness of humans in a web-of-life, and in particular how human-animal relationships are manifest, understood, and unfolded in archaeological situations and contexts. These prerequisites concern not only different ontological perceptions (Descola 20I3; Holbraad \& Pedersen 2017), but also active relationships with humans and nonhumans. These relationships are manifold and complex. As humans can and will engage with non-human animals, different sentient non-human animals possess perspectives and agential possibilities to engage in meaningful relationships with humans. Therefore, human-animal relationships deserve close-up research throughout all archaeological periods, including concurrent relationships in different social and cultural settings.

The enigma of the various natures of human and non-human animal relationships points to several related reasons why archaeologists should consider such relations more thoroughly. First and foremost, something happens when species meet (Haraway 2008). Non-human animals participate in meaningful relations with humans. To explore and try to understand such local complex webs of life will improve our physical and mental health, by lowering the heartrate, helping us recover faster after severe illness and releasing the hormone oxytocin into the bloodstream of both humans and animals when we interact (Cox et al. 20I7). The same is true for engaging with companion animals (Brooks et al. 2018; Halm 2008). Even 'wild' 
animals have the agency and power to develop meaningful relations with humans, which sometimes can help us overcome great despair (Bloom \& Grevie 20I6). Second, throughout history, and around the globe, animals have been attributed with healing powers and used in folk medicine (Estes 1989; Lev 2003; Nóbrega et al. 2013; Tillhagen 1958, I978; Wiseman \& Ellis I996), an area that is relatively unexplored within the field of archaeology. Third, multispecies meetings, intra-actions, and relationships exceed humanity as we know it. In short: before there were humans, no matter what kind of definition we wish to apply, there were web-of-species societies and relations. The becomings of different variations of hominids and human beings are therefore entwined and meshed up in an intricate nonhuman animal web-of-life (Gittins 20I3). These and other multispecies relationships are therefore, for better or worse, at the heart of what make us humans as well as the history of humanness.

Fourth, the intricate relationship between human and non-human beings could also be said to be valid for the becoming of archaeology as a discipline. Archaeology springs from an exploration of humanity from a deep-time perspective, and thus from its beginning contested the theological (biblical) time perception of the world as merely 6000 to 7000 years old (Thomas 2004; Trigger 2006), replacing analogism with naturalism (Descola 20I3; Goldhahn 20I9). What is seldom discussed, however, is that the relationship between human and non-human animals was at the core in distinguishing and rethinking different prehistoric epochs in cultural-historical terms. For example, the finding of an extinct aurochs (Bos primigenius) from Önnarp in Scania in I840, with flint arrowheads still in situ, was crucial for Sven Nilsson (I787-I883) in unfolding the Stone Age as a cultural-historical epoch (Nilsson I838-I843, I868). Other significant relationships between humans and non-human animals that reshaped our perception of the past during the nineteenth century were Jens Jacob Asmussen Worsaae's (I82I-I885) I850s excavation of a Køkkenmødding in Meilgaard, northern Djursland, which lead to the more renown Køkkenmødding commission, and Bror Emil Hildebrand's (I806-I884) finds of domesticates in a megalithic burial monument during the I860s (Hildebrand I869); two famous excavations which brought new understandings about the relationship between human and non-human beings and helped to refigure the Stone Age into a Mesolithic and Neolithic epoch (Fisher \& Kristiansen 2002; Goldhahn 2013).

Likewise, the understanding of the basic subsistence strategy for current western societies since the agricultural revolution and domestication some 9000 years ago (Rudbeck 2000; Clutton-Brock et al. 20I2) also hinges on a fundamental change in the relationships between humans and animals; arguably one from an engagement with animals dominated by hunting, to 
multiple engagements that ranged from hunting to companionship to ethics of care (Armstrong Oma 20I8a). Exciting new finds, such as the multispecies pillars from Göbekli Tepe in today's Turkey (Fagan 2017), as well as new theoretical elaboration of older finds, change our perception of humanity as continuing to be unfolded through our archaeological praxis. Who could envisage that Neanderthals (Radovčić et al. 20I5; Finlayson 20I9), as well as modern humans, shared such a deep-time history and relations with avian creatures (Collar et al. 2007; Johansson 20I2; Kost \& Hussain 2019; Serjeantson 2009)?

A key feature in our approach to these issues is that animals, indisputably, have agency of their own (Armstrong Oma 20I8b; Goldhahn 20I9). Non-human animals are sentient beings which can and will engage in meaningful relations with humans. Our research brings examples of many new multi-species studies within an archaeology that aims to broaden prehistoric agency beyond humanity, which - we argue - will provide a richer, more deeply layered, understanding of past societies.

We picture this momentum in sharp contrast to many recent wellarticulated attempts to activate material culture as 'secondary agents' (Gell I998), which often has been suggested under new notions and theoretical umbrellas, such as the entanglements of different kinds of 'material turns' (e.g. Bennett 20Io; Olsen 20IO; Hodder 20I2), the Object-OrientedOntology of Graham Harman (2002, 20II), or the thought-provoking Agential Realist Ontology of Karen Barad (2007); just to mention a few recent studies that inspired our archaeological praxis. Common for many of the mentioned perspectives, is that they have had a tendency to overemphasize human relations to the material world, and tend to neglect the more often - sincere engagement and commensal bond that exists between humans and sentient non-human animals, which most obviously have an agency of their own.

We find it puzzling that archaeology and anthropology have overlooked such obvious players in the agential life-worlds of humans. For example, we might ask ourselves if it is conceivable to try to understand the so-called Neolithic Revolution (Hodder I990; Barker 2009), or indeed the Secondary Product Revolution (Sherratt I98I, see also Greenfield 20I0; Tornberg 20I8), without discussing humans' changing relations to non-human animals (Armstrong Oma 20I8a; Goldhahn 20I9)?

One possible reason for the explicit focus on human-material relations is that all modern sciences were born within the ontological rationale of humanism that sprang out of a mix of Renaissance enlightenment ideals that put Man at the centre of all things, and the Cartesian separation between mind and body, which posited animals as biological automata (Armstrong Oma 20r8a:45). Despite good intentions, to withhold the supremacy of 
'Man over Beast', and the focus on 'Man and his Things', is clear theological heritage from Christianity. Trying to change this narrative is an uphill struggle, considering how deeply embedded these ideas are into the very fabric of what makes religion religious and science scientific. Researching animal agency is therefore still to some extent uncharted terrain that, we argue, will have ontological implications (Armstrong Oma 2018b; Goldhahn 20I9).

One approach used by some researchers to make headway in this struggle is auto-ethnography (developed from feminist methods), drawing on personal experiences as a tool to make observations and from these, to raise novel kinds of research questions (Game 200I). Such an approach has proved fruitful in opening up the interdisciplinary field of Human-Animal Studies. In our works, on the deeply enmeshed intra-action of herding between herders, sheepdogs, and sheep (Armstrong Oma 20I8a, this volume), and investigating how the birdness of birds contributed in unfolding Bronze Age ontologies (Goldhahn 2019), we have tried to push our boundaries as archaeologists by deep engagement with our subjects of study. Our experience is that the agency of animals does not leave us untouched; it does something to us. Tim Ingold (2OI I:28) called agency "a magical minddust" dreamt by theorists. On the contrary, our experience is that there is nothing dreamy about this. Taken at face value, encounters with animals do have a magical, albeit real-world, component, that rests exactly in their agency, and its inherent unpredictability. To paraphrase Haraway (2008) and Barad (2007): something does happen when species meet and intra-act.

In this context we would like to accentuate that a focus on human and non-human animal relations within archaeological contexts possesses great potential to bring different kinds of archaeologies together. This is highlighted in the different but related contributions to this special section of CSA.

Most of these articles were presented at a workshop entitled Between animals and humans - archaeological perspectives on animated relationships. This gathering was sponsored by the Riksbankens Jubileumsfondan independent $S$ wedish foundation which promotes and supports research in the humanities and social sciences - and held at Linnæus University between II and I3 November 20I8. It gathered 28 participants from America, Australia, Colombia, Denmark, England, Finland, Norway, and Sweden. All in all, I8 papers were presented and discussed. Seven of these are included in this volume of CSA, while those by Jan Magne Gjerde (20I8), Fredrik Hallgren (Gummesson et al. 20I8), Antti Lahelma (20I9), Joanna Lawrence (2019), Magnus Ljunge and Joakim Wehlin (Stockholm University nd), Anja Mansrud (Mjærum \& Mansrud 2020), and Ylva Sjöstrand (2017) have been published elsewhere. Some of the remaining presentations 
will be revealed through ongoing doctoral projects in Denmark and Sweden, and in a future volume of this journal.

Two of the contributions to this special issue focus on our feathered friends. In Tracing the materiality of feathers in the Stone Age northeastern Europe, Kristiina Mannermaa and Tuija Kirkinen argue that archaeologists have neglected the uses of feathers in ritual costumes, everyday clothing, and decoration. Through anthropological studies from across the world, feathers have not only been used as ornaments, but also convey important ontological perceptions about the present past. Bird beings were used as ceremonial paraphernalia and often as personal effigies and symbols for social identities, clans, kinship, and more. By contrast, feathers are extremely rare to uncover through traditional archaeological methodologies, though they seldom survive the test of time. However, through innovative microscopic analyses of soil samples from Mesolithic burials, Mannermaa and Kirkinen have succeeded in revealing the first direct evidence of the use of feathers in burial ceremonies. This opens up momentum to explore the importance of birds and feathers among these hunter and gatherer societies, and beyond.

In To bring back some eagleness to eagles, Joakim Goldhahn reconnoitres how and why humans and eagles and eagles and humans might have intra-acted during the Bronze Age. It is argued that we need to focus on how we assemble our materials not to uncritically recreate our worldings on past ones. Goldhahn uses a blend of eagles' behaviour, birdlore from medieval and more recent times, and analyses of material culture and its find contexts to understand why certain remains and manifestations of eagles were unfolded in the Bronze Age. He argues that many sorts of eagleness were important for worldings during this epoch, some revealed in relations to warriors and warriorhood, others in relation to females, children, and mortuary ceremonies. Eagles were active and intra-acted, possessing an agency of their own.

In the article Fish and humans, Jacob Kveiborg, Laura Svop Ahlqvist, and Helle Vandkilde explore Interspecies relationships in the Nordic Bronze Age. They investigate how new animal-human-thing relationships and associated cosmologies were unfolded and manifested in the formative period of this era. To be able to do so, to examine how past minds, beliefs, and associated practices were played out in different social contexts, Kveiborg et al. argue that we must embrace a holistic approach that encompasses a broad spectrum of archaeological remains and find categories, such as faunal remains, iconography, rock art, and contextual and relational analyses of objects, and more. They use such manifold approaches to outline three complex changes and interactions of significant socioeconomic and cosmological elements, in this case, related to i) horse, sun and humans, ii) sea, 
fish and ships, and iii) fish, fish hooks, and fishing, and how these relationships were played out in life and death. Kveiborg et al. suggest that these elements constituted an 'interconnected parts of an entangled whole,' which represent a new ontology that was revealed between I600 and I400 BCE.

Kveiborg et al. use human-animal relationships to refigure a familiar grand narrative about the European Bronze Age. Armstrong Oma uses them to explore less well-known aspects of these societies' economic and social practices: dogs and their roles in families and farms in association with sheep herding. Few animals show such intelligent interactions with humans as dogs. They bond and quickly become family members, sometimes buried as our peers, and contribute explicitly to everyday arrangements within the household, in playing, guarding, hunting, in raiding and wars, herding, and more. Armstrong Oma focuses on the triad of sheepdog-human interaction. She explores depositional patterns of dog bones in Bronze Age settlements, burials, rock art, and wetland deposits, and how this information can be used to infer an understanding of the ontological role of dogs in social practices concerning herding. The reason for this is simple: sheepdogs embody a unique role between humans and nonhuman animals, and act as active mediators between these agents. Armstrong Oma reveals how sheepdogs and their choreographies contributed to the social spheres of families and societies during the Bronze Age, and - importantly - how we can use human-animal relationships to humanize the past in ways that unfold new aspects of past societies that differ from centuries-old grand narratives.

Rock art is some of the most tangible evidence of humans' intangible perceptions and life-worlds. It has been vital in exploring past and present ontologies and the human-animal relationship. In this special issue, this is manifested through Fuglestvedt's re-examination of possible reindeer herding in the Late Mesolithic in the Alta region. She argues that the 'Neolithic revolution' played out differently among hunters and gatherers in northernmost Europe. Fuglestvedt finds a remarkable difference between the two earliest phases of rock art in the Alta region, manifested through the presence and absence of human control over animals. In the initial phase, she finds a humanization of wild animals expressed by focusing on their inner qualities, their essence: totemism. In the ensuing phase, all big game animals are depicted with a pecked contour or in bas-relief, showing a focus on the animal's outer qualities: animism (see Fuglestvedt 20I8). The former way to depict reindeers is contemporary with depictions of reindeer corrals controlling herds. It is argued that this represents an early phase of small-scale semi-domestication of reindeer. Following Fuglestvedt, changing rock art styles not only reflect changes in human-animal relations, but also unfold changes in people's ontological understanding of the world. 
In Retrieving, curating and depositing skulls on Pitted Ware culture sites, Tobias Lindström explores shared traits in the treatment of human and non-human animal remains during the Middle Neolithic in the Baltic Sea region. His article contests modernistic perceptions which associate skulls with danger, death and our mortality, and explores other ways to make these meaningful. Lindström focuses on how human and nonhuman skulls have been treated and deposited on sites belonging to the Pitted Ware Culture. Many times, the skull handling included depositions of humans and non-human animals within the same archaeological features. Human remains had also been modified in ways that are commonly associated with how animal remains were treated, such as splitting and cutting of long bones and teeth removal. Lindström suggest that these remains were curated to be able to impact on the physical world of the living, and maybe used as heirlooms, charms or memorabilia. In his own words: 'we might be dealing with acts involving parts of the dead without the acts themselves strictly speaking being directed towards the dead'.

Lindström's article shows that relations between how human and nonhuman animals are treated in ritualized practices are vital to explore in our quest to understand the past. Bettina Stolle's article, Ritual slaughter through the eyes of the butcher: Perspectives on a complex practice, can be taken as an example that this also applies to analyses of a specific social practice such as slaughter. Stolle uses both quantitative and qualitative features in her analyses, such as the frequency of cut marks, the force and implements applied to induce them, and the precision and uniformity of the cuts. Sometimes the butchery process is described as intense, referring to elevated levels of one or all of the above stated features. Her analyses contest interpretations that rely on literary sources alone, which often state that slaughter was a ritualized practice. By revealing both similarities and differences in butchery marks on animal bones in the zooarchaeological record, Stolle discloses different kinds of butchery practices. She takes this as an indication that these processes incorporated skilled people from various segments of the society.

\section{Closing}

Reading through this special section of CSA, it is easy to detect a concurrent ambivalence in approaching the relationship between human and nonhuman animals in archaeological studies. This shows that we still battle to come to terms with the naturalism we inherited from Enlightenment and Christian preconceptions. Nerissa Russell (2OI 2: 2-3) has emphasized that the entangled relationships between human and non-human beings expose 
our minds to both anthropocentrism and anthropomorphism. If we create a firm boundary between us and them we will generate an exclusive position for our ontology - anthropocentrism - and vice versa, if we obliterate the boundary between humans and nonhuman beings - anthropomorphism we end up denying these creatures their unique being. We do not think that this ambivalence is easy to solve or come to terms with, and this might be the best reason for focusing our research on the relationships between human and non-human animals: namely that it exposes our preconceptions of ourselves as situated beings with cognitive privileges. This, for us, calls out for moral reflections, not only on human relations to non-human animals in the past, but also in the present. We are all a part of web-of-species societies populated by sentient beings and, we argue, it is time to let this shine true within archaeology.

\section{References}

Andersen, K.G., Rambaut, A., Lipkin, I.A., Holmes, E.C. \& Garry, R.F. 2020. The Proximal Origin of SARS-CoV-2. Nature Medicine. Vol. 26 pp. 450-452.

Armstrong Oma, K. 2018a. The Sheep People. Oxford: Equinox Publishing.

Armstrong Oma, K. 2018b. Making Space from the Position of Duty of Care: Early Bronze Age Human-Sheep Entanglements in Norway. In: Pilaar Birch, S.E. (ed.). Multispecies Archaeology, pp. 214-229. London: Routledge.

Barad, K. 2007. Meeting the Universe Halfway: Quantum Physics and the Entanglement of Matter and Meaning. Durham: Duke University Press.

Barker, G. 2009. The Agricultural Revolution in Prehistory: Why Did Foragers Become Farmers? Oxford: Oxford University Press.

Bennett, J. 20Io. Vibrant Matter: A Political Ecology of Things. London: Duke University Press.

Bloom, C. \& Grevie, B.T. 2016. Penguin Bloom: The Odd Little Bird who Saved a Family. Sydney: Harper Collins Publishers.

Brooks, H.L., Rushton, K. [...] Grant, L. \& Rogers, A. 2018. The Power of Support from Companion Animals for People Living with Mental Health Problems: A Systematic Review and Narrative Synthesis of the Evidence. BMC Psychiatry. Vol. I8(3I) DOI I0.II86/SI2888-0I8-I6I3-2.

Collar, N.J., Long, A.J., Robles Gil, P. \& Rojo, J. 2007. Birds and People: Bonds in a Timeless Journey. Mexico City: Birdlife International.

Cox, D.T.C., Shanahan, D.F. [...] Hancock, S. \& Gaston, K.J. 20I7. Doses of Neighbourhood Nature: The Benefits for Mental Health of Living with Nature. BioScience. Vol. $67(2)$ pp. I $47-155$.

Clutton-Brock, J. \& Kamin, B. 20I2. Animal Turn: Animals as Domesticates: A World View Through History. East Lansing: Michigan State University Press.

Descola, P. 2013. Beyond Nature and Culture. Chicago: University of Chicago Press.

Estes, J.W. 1989. The Medical Skills of Ancient Egypt. Canton: Science History Publication. 
Fagan, A. 20I7. Hungry Architecture: Spaces of Consumption and Predation at Göbekli Tepe. World Archaeology. 49 pp. 318-337.

Finlayson, C. 2019. The Smart Neanderthal: Cave Art, Bird Catching, and the Cognitive Revolution. Oxford: Oxford University Press.

Fischer, A. \& Kristiansen, K. (eds.) 2002. The Neolithisation of Denmark: I50 Years of Debate. Sheffield: J R Collis.

Fuglestvedt, I. 2018. Rock Art and the Wild Mind: Visual Imagery in Mesolithic Northern Europe. London: Routledge.

Game, A. 200I. Riding: Embodying the Centaur. Body \& Society. Vol 7(4) pp. I-I2.

Gell, A. 1998. Art and Agency: An Anthropological Theory. Oxford: Clarendon.

Gittins, E. 20I3. The Archaeology of Becoming the Human Animal. Society \& Animals. Vol. 2I(2) pp. I20-I33.

Gjerde, J.M. 20I8. Marine Mammals in the Rock Art of Alta, Norway, Northernmost Europe. In: Ulsan Petroglyph Museum (ed.). Whale on the Rock II, pp. I77-I92. Ulsan: Ulsan Petroglyph Museum.

Goldhahn, J. 2013. Bredarör på Kivik: En arkeologisk odyssé. Kalmar Studies in Archaeology 9. Kalmar: Linnaeus university.

Goldhahn, J. 2019. Birds in the Bronze Age: A North European Perspective. Cambridge: Cambridge University Press.

Gummesson, S., Hallgren, F. \& Kjellström, A. 2018. Keep your Head High: Skulls on Stakes and Cranial Trauma in Mesolithic Sweden. Antiquity. Vol. 92(36I) pp. 74-90.

Greenfield, H.J. 20I0. The Secondary Products Revolution: The Past, the Present and the Future. World Archaeology. Vol. 4 (I) pp. 29-54.

Halm, M.A. 2008. The Healing Power of the Human-Animal Connection. American Journal of Critical Care. I7(4) pp. 373-376.

Harman, G. 2002. Tool-Being: Heidegger and the Metaphysics of Objects. Peru, IL: Open Court Publishing.

Harman, G. 20I . The Quadruple Object. United Kingdom: Zero Books.

Haraway, D.J. 2008. When Species Meet. Minneapolis: University of Minnesota Press.

Hildebrand, B.E. I869. Till hvilken tid och hvilket folk böra de svenska hällristningarne hänföras? Antiquarisk Tidskrift för Sverige. Vol. II pp. 417-432.

Hodder, I. I990. The Domestication of Europe: Structure and Contingency in Neolithic Societies. Oxford: Basil Blackwell.

Hodder, I. 20I 2. Entangled: An Archaeology of the Relationships Between Humans and Things. Malden: Wiley-Blackwell.

Holbraad, M. \& Pedersen, M.A. 2017. The Ontological Turn: An Anthropological Exposition. Cambridge: Cambridge University Press.

Huang, C., Wang, Y. [...] Wang, J. \& Cao, B. 2020. Clinical Features of Patients Infected with 2019 Novel Coronavirus in Wuhan, China. The Lancet. Vol. 395(I0223) pp. 497506.

Ingold, T. 20I . Being Alive: Essays on Movement, Knowledge and Description. London: Routledge.

Johansson, K. 20I 2. The Birds in the Iliad: Identities, Interactions and Functions. Gothenburg Studies in History 2. Gothenburg: Gothenburg University.

Kohn, E. 20I3. How Forests Think: Toward an Anthropology Beyond the Human. Berkeley: University of California Press. 
Kost, C. \& Hussain, S.T. 20I9. Archaeo-Ornithology: Towards an Archaeology of HumanBird Interfaces. Environmental Archaeology. Vol. 24(4) pp. 337-358.

Lahelma, A. 20I9. Sexy Beasts: Animistic Ontology, Sexuality and Hunter-Gatherer Rock Art in Northern Fennoscandia. Time and Mind. Vol. I2(2) pp. 22 I-238.

Lawrence, J.M. 2019. Sexed Animals in Swedish Southern Tradition Rock Carvings: Gender, Sexuality, Fertility, and Implications for Animals in Bronze Age Ontology. Time and Mind. Vol. I2(2) pp. I37-I5I.

Lev, E. 2003. Traditional Healing with Animals (Zootherapy): Medieval to Present-Day Levantine Practice. Journal of Ethnopharmacology. Vol. 85 pp. I07-I 8.

Mjærum, A. \& Mansrud, A. 2020. Resource Management in Late Mesolithic Eastern Norway: Fishing in the Coastal, Interior and Mountain Areas and its Socio-Economic Implications. In: Schülke, A. (ed.). Coastal Landscapes of the Mesolithic: Human Engagement with the Coast from the Atlantic to the Baltic Sea, pp. 264-299. London/ New York: Routledge.

Nilsson, S. I838-I843. Skandinaviska Nordens Ur-Invånare: Ett Försök i Komparativa Ethnografien och ett Bidrag till Menniskosloegtets Utvecklings-Historia. Stockholm: Norstedt.

Nilsson, S. I868. The Primitive Inhabitants of Scandinavia: An Essay on Comparative Ethnography, and a Contribution to the History of Mankind. $3 \mathrm{rd} \mathrm{ed.} \mathrm{London:} \mathrm{Long-}$ mans, Green, and Co.

Nóbrega A., Rômulo Romeu, R. \& Ierecê L. (eds). 2013. Animals in Traditional Folk Medicine: Implications for Conservation. London/New York: Springer.

Olsen, B. 20Io. In Defense of Things: Archaeology and the Ontology of Objects. Lanham: AltaMira Press.

Pilaar Birch, S.E. (ed.). 20I8. Multispecies Archaeology. London/New York: Routledge.

Radovčić, D., Sršen, A.O., Radovčić, J. \& Frayer, D.W. 2015. Evidence for Neandertal Jewellery: Modified White-Tailed Eagle Claws at Krapina. PLoS ONE. Vol. Io(3) doi: I0.137I/journal.pone.0119802.

Rudebeck, E. 2000. Tilling Nature - Harvesting Culture: Exploring Images of the Human Being in the Transition to Agriculture. Acta Archaeologica Lundensia, Series in $8^{\circ}$, No 32. Lund: Lund University.

Russell, N. 201 2. Social Zooarchaeology: Humans and Animals in Prehistory. Cambridge: Cambridge University Press.

Serjeantson, D. 2009. Birds. Cambridge: Cambridge University Press.

Sherratt, A.G. I98 I. Plough and Pastoralism: Aspects of the Secondary Products Revolution. In: Hodder, I., Isaac, G. \& Hammond, N. (eds). Pattern of the Past: Studies in Honour of David Clarke, pp. 26I-306. Cambridge: Cambridge University Press.

Sjöstrand, Y. 20I7. The Concept of Art as Archaeologically Applicable. Cambridge Archaeological Journal. Vol. 27(2) pp. 37I-388.

Stockholm University. nd. Magnus Odebäck Ljunge. https://www.su.se/profiles/maljo976I.I8793I. [Accessed 4 November 2020].

Thomas, J. 2004. Archaeology and Modernity. London: Routledge.

Tillhagen, C.-H. 1958. Folklig läkekonst. Stockholm: Nordiska Museet.

Tillhagen, C.-H. 1978. Fåglarna i folktron. Stockholm: LT Förlag.

Tornberg, A. 2018. Health, Cattle and Ploughs: Bioarchaeological Consequences of the Secondary Products Revolution in Southern Sweden, 2300-I I0o BCE. Acta Archaeologica Lundensia, Series Altera in $8^{\circ}$, No $7 \mathrm{I}$. Lund: Lund University. 
Trigger, B.G. 2006. A History of Archaeological Thought. 2nd ed. Cambridge: Cambridge University Press.

Wiseman, N. \& Ellis, A. I996. Fundamentals of Chinese Medicine. Brookline: Paradigm Publications. 